\title{
Oath of Government Employees-Based Standards and Organizational Commitment in a Local Government Unit in Central Luzon, Philippines
}

\section{Imelda DP. Soriano ${ }^{1}$}

${ }^{1}$ College Adminitrator, Gordon College. Olongapo City, Philippines.

Article History

Received:

23.09.2021

Revised:

20.10.2021

Accepted:

06.11 .2021

*Corresponding Author:

Imelda DP. Soriano

Email:

soriano.imelda@

gordoncollege.edu.ph

This is an open access article, licensed under: $\mathrm{CC}-\mathrm{BY}-\mathrm{SA}$
Abstract: The study aimed to assess the organizational commitment and the internalization of the standards contained in the Oath of Government Employees (Panunumpa ng Kawani ng Gobyerno) based on the experience of the employee of the Local Government Unit of Olongapo. It will specifically focus on four key result areas reflected in the pledge of commitment: honesty and integrity, proper use of government property, fight against corruptions, technical and professional competencies. The researcher used a descriptive research method and utilized a cross-sectional design with the questionnaire as the main data gathering tool. The population of the study consisted of the employees in the different service-delivery units of a highly urbanized city in Central Luzon, Philippines. A sample size representing ten percent $(10 \%)$ of the total population determined the respondents for the study. The sample respondents were selected among the different service-delivery units of the local government unit using a simple random sampling technique. This study intended to prove the significant difference in the organizational commitment of employees in the local government unit in terms of gender, age, and length of service. Furthermore, the research also tried to determine the relationship between the Oath of Government Employees - Based Standards and Employees Organizational Commitment in the local government unit of the involved highly urbanized city. The result of the study will serve as a basis to develop a proposed Service Charter for each of the service-delivery units of the local government of the City.

Keywords: Highly Urbanized City, Local Government Unit, Oath of Government Employees, Organizational Commitment. 


\section{Introduction}

The issue of work ethics and public accountability poses a continuing challenge to the Philippine government. The mechanisms, processes, and systems that have been put in place, may not yet be the best or ideal in the sense that ethical and accountable behavior in the public sector is still much to be desired in the Philippines. The growing and increasing demands of the citizenry have raised expectations on the civil service. However, there is so much hope to hold, and believe that there will be many opportunities to lead and change for the best. In a related paper, accountability has a multifaceted nature that relates to ethics, democracy, information, human and organizational behavior [1]. Of course, the organizational behavior of employees affects the work ethics and accountability of employees [2].

Moreover, public resources belong to the people. An article showed some practical mechanisms for setting and institutionalizing standards of ethical conduct and governance for civil servants based on experiences from different countries [3]. Civil servants are stewards, caretakers, and agents of the people. Civil servants, therefore, have a moral and legal responsibility to the people to be transparent and accountable in the use of public resources [4]. Transparency in public service refers to clear and accessible service delivery that is free from deceit and encompasses the principles of access to information. A group of researchers proposed a study that focuses on the impact of government involvement on employees' commitment in the public sector. From the result of the study, it served as an empirical source of information due to a dearth of researches in this field [5]. From a different angle, an article predicted that commitment and organizational citizenship behavior have a relationship and commitment mediates between procedural fairness and organizational behavior as well [6]. However, there are also negative aspects for the organization regarding employees' organizational commitment [7]. According to Asio [8], the working environment, teamwork, and diversity affect organizational satisfaction as well. On the other hand, an article also determined some career opportunities and work life of professionals and correlated it to organizational commitment [9].

These demands and challenges have prompted the Office of the President to issue Memorandum Order No. 269 series of 1995 prescribing the inclusion of the "Recitation of Panunumpa ng Kawani $n g$ Gobyerno (Oath of the Government Employees)" as part of the Flag Raising Ceremony on Mondays. This is according to Civil Service Commission (CSC) Memorandum No. 2 s. 1995 and Civil Service Commission (CSC) Resolution No. 95-0598 dated February 7, 1995. The Oath of Government Employees articulates the expected commitment of public servants (see appendix A for the original and English-translated version). In related literature, employees' perception of how well an organization is managed results in a higher organizational commitment which leads to a higher public service motivation [10].

This reform mechanism aims to re-orient the work attitude of government officials and employees by constantly reminding them of how they must conduct themselves as public servants to bring about a more responsive, efficient, and committed public service. Gunawan et al. [11] mentioned that organizational commitment, competence, and good governance affect employees' performance and quality asset management to some extent. In a presentation from a former Philippine Civil Service Commissioner, she attempted to document the effort of the Philippine government in the area of public service where political leaders, policymakers, and public administrators employed initiatives and reforms to resolve the issues of increased demands among the populace [12]. It is equally important to note that some issues and concerns like procrastination also lingers among employees affects work productivity to some extent [13] [14].

Bearing in mind the increasing expectations of effective and efficient public service from the citizens, there is now a need to focus on the areas of concern reflected in the Oath of Government Employees, which are directly relevant to the improvement as well as enhancement of the employees' commitment in the different service-delivery units of the government. Public service is made up of employees covered by national and sub-national civil service laws. These employees play an indispensable role in the sustainable development and good governance of a country [15].

It is against this background that prompted the researchers to document and analyze the efficient and effective implementation and internalization of the standards contained in the Oath of Government Employees based on the experience of the Local Government Unit (LGU) of Olongapo City. Specifically, it will focus on four key result areas reflected in the pledge of commitment namely: a) Honesty and Integrity b) Proper Utilization of Government Property c) Fight Against Corruption d) Technical and Professional Competence 
The study aimed to assess the organizational commitment and the internalization of the standards contained in the Oath of Government Employees based on the experience of the employee of the Local Government Unit of Olongapo.

\section{Methodology}

\subsection{Research Design}

The study used a descriptive type of research. The use of a survey gathered the primary source of data among the eligible respondents for the study. According to Asio [16], a survey includes a numeric assessment based on trends, attitudes, or perspectives of a population. Since descriptive research tries to describe a certain characteristic of a population and analyze it quantitatively, this fits the concept which the current study endeavored by processing the responses from the survey and try to analyze it. The subject that needs analysis here is the oath of a government employee-based standards and the employees' organizational commitment where the researcher attempts to describe its feature and present new results and ideas.

\subsection{Respondents}

The sample of the study consist of 319 employees in the different service-delivery units of a local government unit. A sample size representing twenty percent $(20 \%)$ was determined as the respondents. This number constitutes one thousand five hundred ninety-five (1595) employees of the local government unit. The sample respondents were selected from among the different servicedelivery units of the local government unit using a simple random sampling technique. The inclusion criterion is that the respondent should be knowledgeable of the Oath of Government Employees and a bona fide government employee of the local government unit involved in the study.

\subsection{Instrument of the Study}

The questionnaire checklist was developed by the researcher and was subjected to content validation. It was validated by experts which include a City Administrator, a Chief of the Human Resource Department, and a Director for Human resources of a college. Their suggestions and recommendations were incorporated for the betterment of the research instrument. Before actual data gathering, the instrument also was subjected to a pre-test to some selected students for further verification, clarification, and interpretation.

\subsection{Statistical Analysis}

The accomplished questionnaires were retrieved and the data were tallied, classified, and presented in tables. The data gathered were tabulated, organized, and processed through Microsoft Excel and Statistical Package for Social Sciences version 20 (SPSS v.20) respectively with the use of frequency distribution, weighted mean, t-test, and Analysis of Variance (ANOVA). The samples' responses were derived from a five-point Likert scale.

\section{Results and Discussions}

This section deals with the analysis and interpretation of data in answer to the problems raised in this study. The presentation of data follows the order of the problems listed in the introduction and results of the interview and document analysis.

Table 1 presents the profile of the respondents for the study. As for the discussion, the following essential discussions below explored the data gathered with in depth analysis.

In terms of age. As shown from the table, more respondents were belonging to the 33-39 age group with 58 out of 319 or $18.2 \%$, and the lowest number of respondents belong to the 61-67 years old bracket with $5.3 \%$. Data signifies that this age group represents the highest number of employees delivering different services to the local government units of Olongapo City. This finding revealed that the majority of respondents are in their prime. Several factors, including personal factors (age, tenure in the organization, disposition, internal or external control attributions); organizational factors (job design and the leadership style of one's supervisor), non-organizational factors (availability of alternatives) determine organizational commitment. All these things affect subsequent commitment [17]. Iskandar et al. [18] stated that younger age employee was less knowledgeable on the rule and procedure, which led to them being in the state of being unsure about integrity in the public sector. In turn, the corruption level in Malaysia was high. It, therefore, can be stated that younger age was 
inversely related to perception on the knowledge of integrity, corruption, and quality of service delivery.

Table 1. Profile of the Respondents

\begin{tabular}{|c|c|c|c|}
\hline $\begin{array}{l}\text { Profile Variables } \\
\mathrm{N}=319\end{array}$ & Categories & Frequency & Percentage \\
\hline \multirow{5}{*}{ Gender } & Male & 138 & 43.3 \\
\hline & Female & 181 & 56.7 \\
\hline & Below 20 years old & 7 & 2.2 \\
\hline & $20-29$ & 56 & 17.6 \\
\hline & $30-39$ & 80 & 25.1 \\
\hline \multirow[t]{6}{*}{ Age } & $40-49$ & 75 & 23.5 \\
\hline & $50-59$ & 54 & 16.9 \\
\hline & 60 and above & 21 & 6.6 \\
\hline & No Response & 26 & 8.2 \\
\hline & Below 3 months & 1 & .3 \\
\hline & $\begin{array}{l}3 \text { months to less than } 1 \\
\text { year }\end{array}$ & 22 & 6.9 \\
\hline \multirow{6}{*}{ Length of Service } & $1-3$ years & 75 & 23.5 \\
\hline & 4-7 years & 90 & 28.2 \\
\hline & $8-11$ years & 37 & 11.6 \\
\hline & Above 11 years & 60 & 18.8 \\
\hline & No Response & 34 & 10.7 \\
\hline & $\begin{array}{l}\text { Sub-Professional } \\
\text { (SG 1-10) }\end{array}$ & 174 & 54.5 \\
\hline \multirow[t]{5}{*}{ Salary Grade } & $\begin{array}{l}\text { Professional } \\
\text { (SG 11-24) }\end{array}$ & 63 & 19.7 \\
\hline & $\begin{array}{l}\text { Middle Managers } \\
\text { (SG 25-28) }\end{array}$ & 3 & .9 \\
\hline & No Response & 79 & 24.8 \\
\hline & Single & 139 & 43.5 \\
\hline & Widow/Widower & 14 & 4.4 \\
\hline \multirow[t]{5}{*}{ Marital Status } & Married & 157 & 49.2 \\
\hline & legally Separated & 5 & 1.6 \\
\hline & No Response & 4 & 1.3 \\
\hline & Elementary & 5 & 1.6 \\
\hline & Secondary & 25 & 7.8 \\
\hline \multirow{5}{*}{$\begin{array}{l}\text { Highest Educational } \\
\text { Attainment }\end{array}$} & Vocational courses & 52 & 16.3 \\
\hline & College & 191 & 59.9 \\
\hline & Graduate Studies & 26 & 8.2 \\
\hline & Post Graduate Studies & 14 & 4.4 \\
\hline & No Response & 6 & 1.9 \\
\hline \multirow{4}{*}{ Eligibility } & Sub-Professional & 37 & 11.6 \\
\hline & Professional/PRC & 76 & 23.8 \\
\hline & None of the Above & 163 & 50.5 \\
\hline & No Response & 45 & 14.1 \\
\hline
\end{tabular}

The data reveals that the majority of the respondents are female with $56.6 \%$ or 180 . The male respondents comprise $43.4 \%$ or 138 . This result may imply that gender is not an issue in the local government of Olongapo City. It shows that the different service units of the local government are female-dominated. The city address gender equality and opportunity. Bashevkin [19] reported that 
more than 20 countries currently have a woman holding office in the national government, and the global participation rate of women at the national level is nearly $20 \%$. Several countries are exploring measures that may increase women's participation in government at all levels, from local to national.

As reported in the table, respondents as to marital status, 157 out of 318 or $49.4 \%$ are married; 139 or $43 \%$ are single; 17 or $5.3 \%$ are widowed and $1.6 \%$ or 5 legally separated. The findings revealed that the majority of the respondents tasked to deliver basic government services are married.

Respondents reported highest educational attainment with 190 or $59.7 \%$ possessing bachelor's degree and elementary graduate as the lowest with $1.6 \%$ or 5 . It shows that majority of the respondents obtained formal education such as a bachelor's degree which signifies that respondents are aware of the importance of education to have the security of tenure. In addition, it revealed that the Local Government Unit of Olongapo recruits the "best and the brightest" and has always been one of the major concerns of the government, whether national or local, when it comes to its personnel administration.

165 out of the total numbers of respondents are not civil service eligible; 77 or 24.2 are holders of a professional license issued by the Philippine Regulations Commission (PRC); 39 or 12.3\% have sub-professional eligibility, 37 or $11.6 \%$ refused to indicate their civil service eligibility. This finding revealed that the majority of the respondents operating the different service units of the local government of Olongapo City are without civil service eligibility. It shows that most of the respondents are not aware of the importance of civil service eligibility. The protection of civil servants from arbitrary removal and political neutrality as few to mention.

The data shows that majority of the respondents have been employed with their immediate office for 1-10 years. This is represented by 196 or $61.6 \%$. Only 2 employees or $.6 \%$ have been serving the government for 41-50 years.

It was presented in the table that most of the respondents (116) or 36.5\% belong to salary grades 15 , and only 3 out of the total number of respondents responded with the highest salary grade. This finding revealed that the majority of the respondents belong to regular members

Table 2. Organizational Commitment of the Employees in terms of Honesty and Integrity

\begin{tabular}{lcc}
\hline Indicators & $\begin{array}{c}\text { Weighted } \\
\text { Mean }\end{array}$ & $\begin{array}{c}\text { Descriptive } \\
\text { Rating }\end{array}$ \\
\hline $\begin{array}{l}\text { I can arrive at the office on time. } \\
\text { Naisasagawa ko ang pagpasok sa opisina ayon sa takdang } \\
\text { oras. }\end{array}$ & 4.17 & Often \\
$\begin{array}{l}\text { I begin work at the office on time. } \\
\text { Naguumpisa ako ng pagtatrabaho sa opisina ayon sa } \\
\begin{array}{l}\text { itinakdang oras. } \\
\text { I am willing to work overtime if needed. }\end{array}\end{array}$ & 3.69 & Often \\
$\begin{array}{l}\text { Lubos sa aking loob ang pagtatrabaho nang lampas sa } \\
\text { takdang oras kung kinakailangan. }\end{array}$ & 3.42 & Often \\
$\begin{array}{l}\text { I am polite to those who need government assistance. } \\
\text { Magalang ako sa pakikitungo sa mga nangangailangan ng } \\
\text { serbisyong gobyerno. }\end{array}$ & 4.49 & Always \\
$\begin{array}{l}\text { I can give quick government assistance. } \\
\text { Naisasagawa ko ang makapagbigay ng mabilis na serbisyo sa } \\
\text { nangangailangang mamamayan. }\end{array}$ & 4.00 & Often \\
\hline Overall Weighted Mean & $\mathbf{3 . 9 5}$ & Often \\
\hline
\end{tabular}

*Legend: $\quad 4.21-5.00=$ Always; $3.41-4.20=$ Often; 2.61-3.40= Occasionally; 1.81-2.60 = Seldom; $1.00-1.81=$ Never

As can be gleaned from Table 2, the employees' organizational commitment in terms of Honesty and Integrity obtained a weighted mean of 3.95 with a descriptive rating of Often. The respondents displayed the most commitment to public interest over and above personal interest. The finding suggests that the employees operating the different services areas always extend prompt, courteous, 
and adequate service to the public as reflected in the following items: "I can arrive at the office on time" with 4.17; "I begin work at the office on time with 3.69; "I am willing to work overtime" with 3.42; and "I am polite to those who need government assistance" with 4.49. This aspect is aligned with the expectation of the government that employees shall promote a high standard of ethics in public service. They shall at all times discharge their duties with honesty and integrity.

In an article by Audi \& Patrick [20], they stated that integrity in its wide, integrational sense is known as the key notion to reinforce the clearer and familiarity of any that represents the day-to-day working standards of morality. However, it may use as a substitute for some other notion like honesty which also may cause it to become less clear than the concept it replaces. While integrity in the wide, integrational sense is crucial in upholding good character and moral act; but at the same time, draws to integrity in the sense of morally sound character, are not by themselves a sufficient guide for the specification of character traits or type of action that are the major structure of moral life both in an organization and in other realms.

The constitutional mandate of accountability and service with utmost responsibility honesty and integrity is well observed in the City of Olongapo interviews showed that government employees of LGU Olongapo complied with the norms of personal conduct. The following forms of personal conduct include the following: commitment to the organization, public interest, professionalism, justness honesty, and sincerity. According to Bihasa [21] commitment to the public interest requires government officials and employees to set aside personal interest in serving the public. In the performance of their duties, the primary consideration must be to benefit the public who needs the government services. Professionalism obliges government officials and employees to discharge their functions with dedication and sincerity. They should create an impression that individuals in the government service are not peddlers of undue patronage. Justness and sincerity oblige government officials and employees to be fair in dealings with the clients of all government agencies.

Table 3. Organizational Commitment of the Employees in terms of Proper Utilization of Government Property

\begin{tabular}{|c|c|c|c|}
\hline \multicolumn{2}{|c|}{ Indicators } & \multirow{2}{*}{$\begin{array}{c}\text { Weighted } \\
\text { Mean } \\
\\
\\
.25\end{array}$} & \multirow{2}{*}{$\begin{array}{c}\text { Descriptive } \\
\text { Rating } \\
\text { Often }\end{array}$} \\
\hline 1. & $\begin{array}{l}\text { I submit an inventory of items in my office at the schedule } \\
\text { required by the government. } \\
\text { Nagsasagawa ako ng imbentaryo ng mga gamit ng } \\
\text { pamahalaan na nasa aking opisina ayon sa itinakda ng lokal } \\
\text { na pamahalaan. }\end{array}$ & & \\
\hline 2. & $\begin{array}{l}\text { I never bring home office supplies from the government. } \\
\text { Hindi kailanman ako nag-uwi sa bahay ng mga gamit sa aking } \\
\text { opisina (katulad ng papel, balpen, stapler, at iba pa). }\end{array}$ & 4.23 & Always \\
\hline 3. & $\begin{array}{l}\text { I give importance to the proper use and conservation of items } \\
\text { owned by the government. } \\
\text { Mataas ang antas ng aking pangangalaga at pagtitipid sa } \\
\text { paggamit ng mga pag-aari ng gobyerno. }\end{array}$ & 4.21 & Always \\
\hline 4. & $\begin{array}{l}\text { I make sure that I request the exact number of items needed in } \\
\text { my office. } \\
\text { Naaayon sa pangangailangan ng aking opisina ang paghingi } \\
\text { at paggamit ng mga pag-aari ng gobyerno. }\end{array}$ & 4.56 & Always \\
\hline 5. & $\begin{array}{l}\text { We are regularly given training about the proper utilization } \\
\text { and conservation of government property. } \\
\text { Nabibigyan kami ng sapat na "training" tungkol sa mga } \\
\text { bagay at prosesong may kinalaman sa wastong pangangalaga } \\
\text { ng mga pag-aari ng gobyerno. }\end{array}$ & 2.87 & Occasionally \\
\hline \multicolumn{2}{|r|}{ Overall Weighted Mean } & 3.82 & Often \\
\hline
\end{tabular}


Table 3 presents the organizational commitment of the respondents in terms of proper utilization of government property. As shown from the table, the organizational commitment of the employees obtained a weighted mean of 3.82 , which has a descriptive rating of "often". The following items that garnered the descriptive rating of "always" are as follows: "I never bring home office supplies from the government with 4.23; "I give importance to the proper use and conservation of items owned by the government with 4.21; and "I make sure that I request for the exact number of items needed in my office" with 4.56. The government employees of LGU Olongapo City displayed a high commitment to the efficient, effective, honest, and economic utilization of government resources. This attitude will redound to the avoidance of wastage in public funds and physical resources. However, the items needing attention and enhancement are those connected with "submitting an inventory of items at the schedule required by the government with a weighted mean of 3.25 and "regular training about the proper utilization and conservation of government property with a weighted mean of 2.87. It only shows that employees need proper orientation on this item. Such training will shed light on those employees who do not care about wasting and utilizing government properties. According to Section 2 of PD 1445 [22] otherwise known as the "State Auditing of the Philippines states that "all resources of the government shall be managed, expended, or utilized following laws, regulations, and safeguarded against loss or wastage through illegal and improper disposition with the view of ensuring economy, efficiency, effectiveness in the operation of the government."

In general, some of the informants generally feel a sense of responsibility to take care of the property and manage them well for the benefit of the people whom they serve. Their being responsible shows primary reasons for their commitment to the organization whom they served.

Table 4. Organizational Commitment of the Employees in terms of Fight against Corruption

\begin{tabular}{|c|c|c|c|}
\hline \multicolumn{2}{|c|}{ Indicators } & \multirow{2}{*}{$\begin{array}{c}\text { Weighed } \\
\text { Mean } \\
4.48\end{array}$} & \multirow{2}{*}{$\begin{array}{c}\begin{array}{c}\text { Descriptive } \\
\text { Rating }\end{array} \\
\text { Always }\end{array}$} \\
\hline 1. & $\begin{array}{l}\text { I have never and will never accept bribes from anyone. } \\
\text { Hindi ako kailanman tumanggap at tatanggap ng suhol } \\
\text { kaninuman. }\end{array}$ & & \\
\hline 2. & $\begin{array}{l}\text { I dare to report any form of corruption that I see from my } \\
\text { fellow government employees. } \\
\text { May lakas loob akong isiwalat ang mga nakikita kong } \\
\text { katiwalian at pagsasamantala ng mga kawani ng } \\
\text { gobyerno. }\end{array}$ & 3.15 & Often \\
\hline 3. & $\begin{array}{l}\text { I have high regard and respect for myself so I will not take } \\
\text { advantage of anyone. } \\
\text { Mataas ang antas ng respeto ko sa aking sarili kung kaya't } \\
\text { hindi ko kayang manamantala sa aking kapwa. }\end{array}$ & 4.81 & Always \\
\hline 4. & $\begin{array}{l}\text { I am contented with the compensation I receive from the } \\
\text { government. } \\
\text { Kuntento ako sa aking tinatanggap ng pasahod ng } \\
\text { pamahalaan. }\end{array}$ & 4.15 & Often \\
\hline 5. & $\begin{array}{l}\text { I can perform my duties well without any strings attached. } \\
\text { Nagagawa ko ang aking sinumpaang tungkulin bilang } \\
\text { kawani ng pamahalaan ng walang anumang kapalit na } \\
\text { hinihintay kaninuman. }\end{array}$ & 4.79 & Always \\
\hline \multicolumn{2}{|r|}{ Overall Weighted Mean } & 4.27 & Always \\
\hline
\end{tabular}

Table 4 presents the organizational commitment of the employees of LGU Olongapo City in terms of the fight against corruption. As shown in the table, the organizational commitment of employees obtained a weighted mean of 4.27 with a descriptive rating of "always". This finding concurred with 
that of the ethical standards for government officials to wit: “... they shall refrain from doing acts contrary to law, good moral, good customs and public interest." They shall not dispense or extend undue favors because of their office. Likewise, employees and their families shall lead modest lives appropriate to their income. They shall not indulge in an extravagant display of wealth in any form.

In the Philippines, the practice of "graft and corruption" is said to be deeply rooted in the culture that exists among the people [21]. In line with the principle that "public office is a public trust", the government of the Philippines is regularly pursuing a rigorous campaign against the practice of graft and corruption and its perpetrators. To strengthen this campaign, the government enacted into law, Republic Act 3019 [23] otherwise known as "Anti-Graft and Corruption Practices Act" which reiterated the call to repress certain acts of public officers and private persons that constitute graft and corruption.

Table 5. Organizational Commitment of the Employees of LGU Olongapo in terms of Increasing Technical and Professional Competencies

\begin{tabular}{lll}
\hline Indicators & $\begin{array}{l}\text { Weighted } \\
\text { Mean }\end{array}$ & $\begin{array}{l}\text { Descriptive } \\
\text { Rating }\end{array}$ \\
\hline $\begin{array}{l}\text { I have the desire to improve myself by pursuing graduate studies. } \\
\text { 1. Mataas ang sidhiin kong madagdagan ang aking kaalaman at }\end{array}$ & 4.08 & Often \\
kakayahan sa pamamagitan ng pag-aaral sa "graduate school" & & \\
I know that attending seminars, workshops, and conferences will \\
make me a more responsible and competent government employee. \\
2. Ang pag attend ng seminars, workshops at conferences ay \\
makabubuti sa aking pagiging responsableng at karapatdapat na \\
kawani ng pamahalaan.
\end{tabular}

Table 5 presents the organizational commitment of the employees of the LGU Olongapo City in terms of increasing knowledge and capabilities. As can be gleaned from the table, the job commitment of employees obtained an overall mean of 4.66, which is interpreted as "always". This finding indicates the employees' willingness to upgrade themselves through the following activities: "pursuing graduate studies with a weighted mean of 4.68; "attending seminars, workshops, and conferences with 4.72; and "reading and research" with 4.65. As government employees, they are expected to discharge their duties with the highest degree of excellence, professionalism, intelligence and skill, and competence.

Competence is a very important role in governance. Because the success of an organization becomes an important work in realizing the objectives to be achieved. Context of competence is an 
important baseline characteristic in a person who is predicted to realize the success of the work. Competence can be understood as a factor that distinguishes a person able to show optimal performance from someone who is not able to perform optimally. Competence is a collection of potentials that dynamically show the intellectual capacity, mental attitude, and the quality of one's social capabilities [24]. The studies of competence in the context of the field of asset management performance are understood as an employee's capability in handling and provide decision-making related to the profession in the field of asset management goods. Because the notion of competence is equated with asset management competence, as executor in finance that understands and have a working principle in developing capabilities based on motives, talents, self-concepts, knowledge, and skills in financial management. Competencies are the areas of knowledge, abilities, and skills that increase an individual's effectiveness in dealing with the world [25]. Competence becomes an important part of the success of the performance-based asset management in realizing the objectives of the organization. Competence comes from the competent who means being able to commensurate with the word ability or ability to do a task or profession that was involved.

Table 6. Variances in the Responses of Employees' Reflection of the Oath of Government Employees - Based Standards according to Profile Variables

\begin{tabular}{lcccc}
\hline Variables & $\begin{array}{c}\text { Honesty and } \\
\text { Integrity }\end{array}$ & $\begin{array}{c}\text { Efficiency and } \\
\text { Responsibility }\end{array}$ & $\begin{array}{c}\text { Fight Against } \\
\text { Corruption }\end{array}$ & $\begin{array}{c}\text { Technical and } \\
\text { Professional } \\
\text { Competence }\end{array}$ \\
\hline Sex & $t=1.46$ & $t=3.41$ & $t=0.18$ & $t=2.73$ \\
Age & $p=.23$ & $p=.07$ & $p=.67$ & $p=.10$ \\
Marital Status & $F=1.46$ & $F=1.46$ & $F=1.46$ & $F=1.46$ \\
& $p=.23$ & $p=.23$ & $p=.23$ & $p=.23$ \\
Educational & $F=0.83$ & $F=0.58$ & $F=0.59$ & $F=1.08$ \\
Attainment & $F=.53$ & $p=.72$ & $p=.71$ & $p=.37$ \\
Civil Service & $p=.08$ & $F=1.35$ & $F=0.94$ & $F=0.92$ \\
Eligibility & $F=1.06$ & $p=.24$ & $p=.46$ & $p=.47$ \\
Length & $p=.37$ & $F=0.64$ & $F=0.73$ & $F=0.72$ \\
Service & $F=1.63$ & $p=.59$ & $p=.53$ & $p=.54$ \\
Salary Grade & $p=.15$ & $F=1.29$ & $F=0.85$ & $F=0.82$ \\
& $F=0.19$ & $p=.27$ & $p=.51$ & $p=.54$ \\
& $p=.83$ & $F=1.99$ & $F=2.60$ & $F=1.58$ \\
& & $p=.14$ & $p=.08$ & $p=.21$ \\
\hline
\end{tabular}

Table 6 showed the variances in the responses of the employees on the oath of government employees-based standards when grouped according to their profiles. In general, we see no significant variation from the answers of the respondents from the four general standards indicated by the study. For the first standard, honesty, and integrity, there were no significant differences in responses when employees were grouped according to sex, age, marital status, educational attainment, eligibility, length of service, and salary grade. The same was observed with the second standard, efficiency, and responsibility, there were no substantial differences in the employees' answers even when they were grouped according to sex, age, marital status, educational attainment, eligibility, length of service, and salary grade. In a related article, a group of writers introduced frameworks of reform imperatives addressing issues about inefficiencies in the government [26]. In terms of the fight against corruption standards, still, there were no significant differences in the responses of the employees. A related study posited that corruption is a problem which all governments, at any level have to deal with, thus, perspectives regarding such ideas do not differ as much [27]. Finally, for the technical and professional competencies, there was also no substantial evidence of differences in the response of the employees. The following generalization was made due to the probability results of every profile variable produced a result that is greater than the alpha significance level of .05 . Therefore, it is safe to assume that there were no significant differences in the oath of the government employees - based standards. In a related article, a researcher revealed that a relationship exists between performance reviews and organizational climate [28]. Thus, reviewing these essential roles 
and responsibilities of government employees contributes to a better organizational climate leading to a better public service.

\section{Conclusion}

Based on the findings of the study, the following conclusions were drawn by the researcher. There were more female respondents than the male counterparts. Also, most of the respondents were between 30-39 years of age with salary grades between SG 1-10. Finally, most of them are married and were college graduates. With the Oath of Government Employees-Based Standards and organizational commitment of the employees, the respondents rated honesty, integrity, and proper utilization of government properties "often". On the other hand, the respondents rated the fight against corruption and talent and capabilities "always".

Based on the conclusions drawn, the following recommendations are hereby advanced by the researcher: (1) The younger age government employees whose less knowledgeable on the rule and procedures which led them to the state of being unsure about organizational commitment should be given training, seminar, and reorientation so that their commitment will be deepened. (2) Reinforce and deepen the explanation of the Based-Standards reflected in the Oath of the Government Employees so that there will be clearer and familiarity with the standards and improve their commitment to the organization. (3) Encourage government employees who are not civil service eligible to take the CSC examination. Reorient them on how important civil service eligibility is. Let them realize the protection of civil servants from arbitrary removal and political neutrality. (4) Improve salary grade of government employees of LGU Olongapo. Recommend to the chief executive promotions and opening of higher plantilla (permanent) position, which is relevant to the job for those who are qualified and eligible to improve organizational commitment. (5) Recommend to the chief executive to form a committee for the development of the service charter of every service delivery unit of the LGU Olongapo.

\section{References}

[1] D. Vandaggombo and V. Radnaasumberel, Ethics and Accountability: Motives of Public Servants in Mongolia, n.d.

[2] F. Luthans, B. C. Luthans, and K. W. Luthans, Organizational behavior an evidencebasedapproach. Charlotte, NC: Information Age Publishing, Inc, 2021.

[3] H. Whitton, "Implementing Effective Ethics Standards in Government and the Civil Service," [Online]. Available: https://www.oecd.org/mena/governance/35521740.pdf. [Accessed: September 2021].

[4] P. Guevarra, Ethics, integrity, and accountability for good governance. [Online]. Available: http://www.csc.gov.ph/speech/418-ethics,-integrity,-and-accountability-for-good-governance. html. [Accessed: September 2021].

[5] M. Oyelere, J. Opute, and P. Akinsowon, Organizational Commitment among Employees. A Developing Nation Perspective: The Case of Nigeria's Public Sector. UK: Regents University London, 2015.

[6] J. J. Lavelle, J. Brockner, M. A. Konovsky, K. H. Price, A. B. Henley, A. Taneja, and V. Vinekar, "Commitment, procedural fairness, and organizational citizenship behavior: A multifoci analysis," Journal of Organizational Behavior, vol. 30, no. 3, pp. 337-357, 2009.

[7] G. Genevičiūtè-Janonienè and A. Endriulaitienè, "Employees' organizational commitment: Its negative aspects for organizations," Procedia - Social and Behavioral Sciences, vol. 140, pp. 558-564, 2014.

[8] J. M. Asio, "Effects and relationships of working environment, teamwork, and diversity to organizational satisfaction," Interdisciplinary Research Review. [Online]. Available: https://ph02.tci-thaijo.org/index.php/jtir/article/view/242200. [Accessed: 20-Sep-2021].

[9] S. Bashir and M. I. Ramay, "Determinants of Organizational Commitment: A study of information technology professionals in Pakistan," Journal of Behavioral and Applied Management, 2008.

[10] E. Camilleri and B. I. J. M. Van Der Heijden, "Organizational commitment, public Service motivation, and performance within the public sector," Public Performance \& Management Review, vol. 31, no. 2, pp. 241-274, 2007. 
[11] H. Gunawan, M. Haming, J. Zakaria, and A. Djamareng, "Effect of organizational commitment, competence and good governance on employees performance and quality asset management," IRA-International Journal of Management \& Social Sciences (ISSN 2455-2267), vol. 8, no. 1, p. 17, 2017.

[12] C. A. G. De Leon, "Reforms in the civil service: The Philippine experience," [Online]. Available: https://silo.tips/download/reforms-in-the-civil-service-the-philippine-experience-by. [Accessed: 20-Sep-2021].

[13] J. M. R. Asio, "Procrastination and work productivity of academic staff: Implications to the institution," Shanlax International Journal of Arts, Science and Humanities, vol. 9, no. 1, pp. 46-53, 2021.

[14] J. M. R. Asio, "Demographic profiles and procrastination of employees: Relationships and determinants," International Journal of Humanities, Arts and Social Sciences, vol. 7, no. 1, pp. 36-46, 2021.

[15] Department of Economic and Social Affairs, "Professionalism and Ethics in the Public Service," United Nations. [Online]. Available: https://publicadministration.un.org/publications/ content/PDFs/E-Library\%20Archives/2000\%20Professionalism\%20and\%20Ethics\%20in\%20 the\%20 Public\%20Service.pdf. [Accessed: September 2021].

[16] J. M. R. Asio, "Research designs in the new normal: A brief overview," Academia Letters, pp. $1-8,2021$.

[17] T. Northcraft and H. Neale, Organization Behaviour. London: Prentice-Hall, 1996.

[18] T. M. Iskandar, M. M. Rahmat, N. M. Noor, N. M. Saleh, and M. J. Ali, "Corporate governance and going concern Problems: Evidence from Malaysia," International Journal of Corporate Governance, vol. 2, no. 2, pp. 119-139, 2011.

[19] S. B. Bashevkin, Women, Power, Politics: The Hidden Story of Canada's Unfinished Democracy. Don Mills, Ont.: Oxford University Press, 2009.

[20] R. Audi and P. E. Murphy, "The many faces of integrity," Business Ethics Quarterly, 01-Jan1970. [Online]. Available: https://econpapers.repec.org/article/cupbuetqu/v_3a16_3ay_3a2006_ 3ai_3a01_3ap_3a3-21_5f00.htm. [Accessed: 20-Sep-2021].

[21] C. R. Bihasa, Introduction to Public Administration. Mandaluyong City: Books ATBP. Publishing Corp., 2014.

[22] Law, "Ordaining and Instituting a Government Auditing Code of the Philippines," Presidential Decree. [Online]. Available: https://gppb.gov.ph/laws/laws/PD_1445.pdf. [Accessed: September 2021].

[23] Law, "Anti-Graft and Corruption Practices Act," the LawPhil Project, Metro Manila. [Online]. Available: https://www.lawphil.net/statutes/repacts/ra1960/ra_3019_1960.html. [Accessed: September 2021].

[24] J. Martin, "Organizational culture: Mapping the terrain," Sage Publication, 2002.

[25] W. M. Cohen, "Fifty years of empirical studies of innovative activity and performance," Handbook of The Economics of Innovation, vol. 1, pp. 129-213, 2010.

[26] A. B. Brillantes and M. T. F. T. Fernandez, "Restoring Trust and Building Integrity in Government: Issues and Concerns in the Philippines and Areas for Reform," International Public Management Review, vol. 12, no. 2, 2011.

[27] J. Balboa and E. Medalla, "Anti-Corruption and governance: the Philippine Experience," Scribd, 2006. [Online]. Available: https://www.scribd.com/document/92938956/AntiCorruption-and-Governance-The-Philippine-Experience. [Accessed: 20-Sep-2021].

[28] J. M. Asio, "Effect of performance review and faculty development to organizational climate," International Journal of Management, Technology, and Social Sciences, vol. 5, no. 2, pp. 1-10, 2020 . 